\title{
Contractile Characteristics of Rat Mesenteric Artery after Organ Culture
}

\author{
Tomoka MORITA $^{1)}$, Hideyuki YAMAWAKI ${ }^{1) *}$, Muneyoshi OKADA ${ }^{1)}$ and Yukio HARA ${ }^{1)}$ \\ ${ }^{1)}$ Laboratory of Veterinary Pharmacology, School of Veterinary Medicine, Kitasato University, Aomori 034-8628, Japan
}

(Received 14 May 2010/Accepted 27 July 2010/Published online in J-STAGE 10 August 2010)

\begin{abstract}
Organ culture of blood vessels is a useful technique to analyze long-term effects of drugs. Various growth factors are responsible for structural and functional changes during vascular remodeling. We investigated 1) basic contractile characteristics in organ-cultured rat mesenteric arteries (MA) in serum-free condition and 2) long-term effects of fetal bovine serum (FBS). Rat isolated MA with $[\mathrm{E}(+)]$ or without $[\mathrm{E}(-)]$ endothelium were divided into 1) freshly isolated (fresh), 2) cultured for 3 days without FBS (control) or 3) with $10 \%$ FBS (FBS). In E (+) control, maximal contraction by noradrenaline (NA), endothelin (ET)-1 and 5-hydroxytriptamine (5-HT) was similar to that in fresh. In E (-) control, maximal contraction by NA decreased whereas that by ET-1 and 5-HT didn't change from fresh. In E (+) FBS, maximal contraction by NA, ET-1, and 5-HT increased from control. In E (-) FBS, maximal contraction by NA and ET-1 decreased whereas that by 5-HT increased. In E (+) or E (-) control and FBS, sensitivity to NA and ET-1 increased from fresh. In E (+) and E (-) control, sensitivity to 5-HT decreased from fresh, and that in FBS further decreased from control. Three-day organ-cultured rat MA in serum-free condition preserved enough contraction to enable analysis for long-term effects of drug. In FBS, maximal contractions by NA and ET-1 increased in E (+) and decreased in E (-) from control, while those by 5-HT increased in both $\mathrm{E}(+)$ and $\mathrm{E}(-)$.

KEY WORDS: blood vessel, cardiovascular pharmacology, contraction, growth factor, smooth muscle.
\end{abstract}

J. Vet. Med. Sci. 72(12): 1621-1627, 2010

In order to sturdy the long-term effects of drugs, animal models have been used extensively. However, due to complicated in vivo kinetics and individual differences, analysis and interpretation of data is often difficult. In contrast, cell culture techniques make it possible to investigate direct effects of drugs and easily control experimental conditions. However, in the cell culture condition, tissue architectures and tissue specific functions are not completely preserved. Furthermore, it is difficult to examine the long-term effects of drugs using cultured vascular cells. Organ culture of blood vessels is thought to be a useful technique to analyze the long-term effects of drugs because it is possible to free from complicated factors existing in vivo and better preserve the differentiated cell functions [21, 22].

Due to easy handling and management, rats have been used widely in the fields of experimental medicine such as physiology and pharmacology. A rat genome has been clarified, and the most rat genes correspond to those of humans and mice [4]. Since inbred and mutant strains have been established in rats, experiments using rats are reproducible and reliable. However, there are only a few reports that investigated the basic contractile characteristics after longterm organ culture of rat mesenteric artery.

Vascular remodeling occurs in cardiovascular disorders such as hypertension, atherosclerosis and diabetes. Various growth factors generated in the lesion are responsible for the structural changes by chronically affecting on the vessel wall and making vascular endothelial and smooth muscle cells to dedifferentiate and proliferate or migrate [15].

\footnotetext{
* Correspondence to: Yamawaki, H., Laboratory of Veterinary Pharmacology, School of Veterinary Medicine, Kitasato University, Towada, Aomori 034-8628, Japan.

e-mail: yamawaki@vmas.kitasato-u.ac.jp
}

The aim of the present study is 1) to investigate the basic contractile characteristics in organ-cultured rat mesenteric arteries compared with the freshly isolated ones, and 2) to study long-term effects of FBS, which contained indefinite but various growth factors on the contractile properties.

\section{MATERIALS AND METHODS}

Tissue preparation and organ culture procedure: Male Wistar rats (205-385 g, 6-12-week-old) were anesthetized with urethane $(1.5 \mathrm{~g} / \mathrm{kg}$, i.p.) and euthanized by an exsanguination. The main branch of the superior mesenteric artery was isolated under sterile conditions. After removal of fat and adventitia in Tris-buffered saline (TBS), the mesenteric artery was cut into rings (1-mm in diameter) for organ culture and measurement of isometric tension. In some experiments, the endothelium was removed by rubbing the intimal surface with a flat face of a pair of forceps. Arterial rings were then placed in $2 \mathrm{~m} l$ Dulbecco's Modified Eagle Medium (DMEM) without (control) or with 10\% FBS (FBS) supplemented with $1 \%$ penicillin-streptomycin. They were maintained at $37^{\circ} \mathrm{C}$ in an atmosphere of $95 \%$ air and $5 \% \mathrm{CO}_{2}$ for 3 days. Freshly isolated arteries (fresh) were prepared as described above but without the use of sterile conditions. Animal care and treatment were conducted in conformity with institutional guidelines of the Kitasato University.

Measurement of muscle tension: The arterial rings were placed in normal physiological salt solution (PSS), which contained (mM): $\mathrm{NaCl} 139.9, \mathrm{KCl} 5.4, \mathrm{CaCl}_{2} 1.5, \mathrm{MgCl}_{2}$ 1.0, $\mathrm{NaHCO}_{3} 23.8$, and glucose 5.5. Ethylendiaminetetraacetic acid (EDTA), $1 \mu \mathrm{M}$, was also added to remove the contaminating heavy metal ions which catalyze oxidation of 
organic chemicals. The high $\mathrm{K}^{+}(72.4 \mathrm{mM})$ solution was prepared by replacing $\mathrm{NaCl}$ with equimolar $\mathrm{KCl}$. These solutions were saturated with a $95 \% \mathrm{O}_{2}-5 \% \mathrm{CO}_{2}$ mixture at $37^{\circ} \mathrm{C}$ and $\mathrm{pH}$ 7.4. Smooth muscle contractility was recorded isometrically with a force-displacement transducer (Nihon Kohden, Tokyo, Japan) as described previously [12, 13]. Each muscle ring was attached to a holder under a resting tension of $0.5 \mathrm{~g}$. After equilibration for $30 \mathrm{~min}$ in a $3 \mathrm{ml}$ organ bath, each ring was repeatedly exposed to high $\mathrm{K}^{+}$ solution until the responses became stable (60-90 min). Concentration-response curves were obtained by the cumulative application of agonists.

Chemicals: The chemicals used were as follows: noradrenaline (NA), endothelin (ET)-1, 5-hydroxytriptamine (5HT) and DMEM (Sigma-Aldrich, St. Louis, MO, U.S.A.); FBS and Penicillin-Streptomycine (Invitrogen/GIBCO, Carlsbad, CA, U.S.A.). 5-HT was dissolved in $\mathrm{HCl}(0.1 \mathrm{~N})$. Others were dissolved in distilled water.

Statistics: The results of the experiments are expressed as means \pm SEM. Statistical evaluation of the data was performed by ANOVA followed by Bonferroni's test for comparisons of three groups (fresh, control, and FBS). A value of $P<0.05$ was taken as statistically significant. The concentration of an agonist required for the half maximal effect $\left(\mathrm{EC}_{50}\right)$ was determined by sigmoidal curve fitting using a SigmaPlot software (Jandel Scientific, Richmond, CA, U.S.A.). All $\mathrm{pD}_{2}$ values were calculated as the $-\log _{10} \mathrm{EC}_{50}$.

\section{RESULTS}

Noradrenaline (NA)-induced contraction in organ-cultured endothelium-intact rat mesenteric arteries: In freshly isolated endothelium-intact arteries [E (+) fresh], NA (1 $\mathrm{nM}-1 \mu \mathrm{M})$ induced contraction in a concentration-dependent manner with a maximal force of $1.61 \pm 0.18 \mathrm{~g} / \mathrm{mg}$ tissue wet weight (w.w.) (n=28, Fig. 1A). In organ-cultured endothelium-intact arteries under serum-free condition [E (+) control], NA ( $1 \mathrm{nM}-1 \mu \mathrm{M})$ caused contraction with a similar but slightly decreased maximal force compared with that in $\mathrm{E}(+)$ fresh $(0.93 \pm 0.18 \mathrm{~g} / \mathrm{mg} \mathrm{w} . w ., \mathrm{n}=10$, Fig. $1 \mathrm{~A})$. In organ-cultured endothelium-intact arteries in the presence of FBS [E (+) FBS], NA $(1 \mathrm{nM}-1 \mu \mathrm{M})$ caused contraction with a similar but slightly increased maximal force compared with that in $\mathrm{E}(+)$ control $(1.23 \pm 0.28 \mathrm{~g} / \mathrm{mg}$ w.w., $\mathrm{n}=8$, Fig. 1A). The concentration-response curve in $\mathrm{E}(+)$ control significantly shifted to the left compared with that in $\mathrm{E}(+)$ fresh when normalized to the maximal force [Fig. 1B; $\mathrm{pD}_{2}$ for the $\mathrm{E}(+)$ fresh and $\mathrm{E}(+)$ control was 7.04 and 7.86 , respectively]. The concentration-response curve to NA in $\mathrm{E}$ $(+)$ FBS didn't change compared with that in $\mathrm{E}(+)$ control $\left(\mathrm{pD}_{2}\right.$ for the $\left.\mathrm{E}(+) \mathrm{FBS} ; 7.88\right)$.

NA-induced contraction in organ-cultured endotheliumdenuded rat mesenteric arteries: In endothelium-denuded fresh arteries [E (-) fresh], NA $(1 \mathrm{nM}-1 \mu \mathrm{M})$ induced contraction in a concentration-dependent manner with a maximal force of $1.59 \pm 0.17 \mathrm{~g} / \mathrm{mg} \mathrm{w} . \mathrm{w}$. ( $\mathrm{n}=26$, Fig. 2A). In organ-cultured endothelium-denuded arteries under serum-

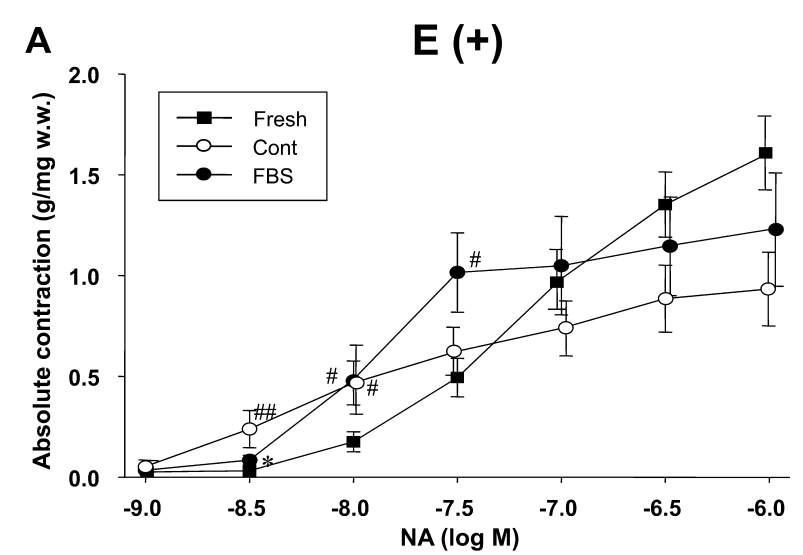

B

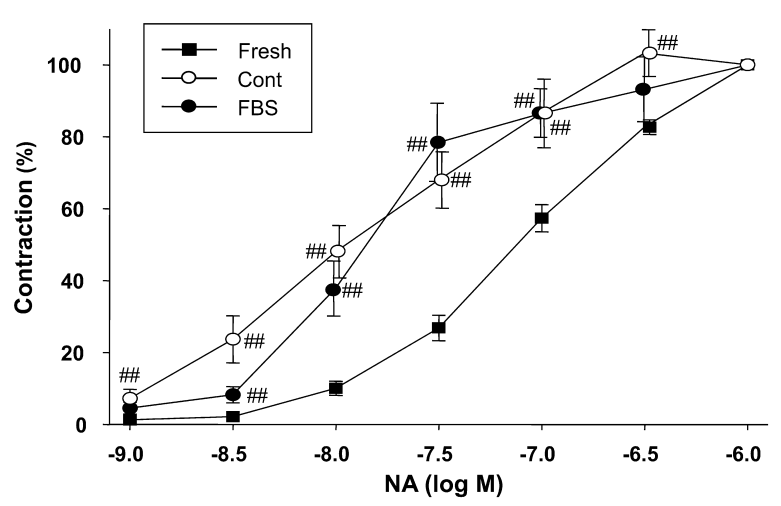

Fig. 1. Concentration-contraction relationship for noradrenaline (NA) in an endothelium intact [E (+)] rat mesenteric arteries; freshly isolated (fresh) or cultured in serum-free medium (cont) and with 10\% FBS (FBS). Contraction was expressed as an absolute value [A: g/mg tissue wet weight (w.w.)] or normalized to the maximal contraction induced by $1 \mu \mathrm{M}$ NA (B). NA $(1 \mathrm{nM}-1 \mu \mathrm{M})$ was cumulatively applied. $100 \%$ represents the $1 \mu \mathrm{M}$ NA-induced maximal contraction. Results are expressed as means \pm SEM [fresh: $n=28$, control: $n=10$, FBS: $n=8$ (A); fresh: $n=29$, control: $n=10$, FBS: $n=8$ (B)]. \#, \#\# : Significantly different with $P<0.05$ and 0.01 vs. fresh. * : Significantly different with $P<0.05$ vs. control.

free condition [E (-) control], the maximal contractile force induced by NA $(1 \mu \mathrm{M})$ significantly decreased compared with that in $\mathrm{E}(-)$ fresh $(1.01 \pm 0.24 \mathrm{~g} / \mathrm{mg} \mathrm{w} . w ., \mathrm{n}=18$, Fig. $2 \mathrm{~A}, P<0.05)$. In organ-cultured endothelium-denuded arteries in the presence of FBS (E (-) FBS), NA (1 nM-1 $\mu \mathrm{M})$ caused contraction with a decreased maximal force compared with that in $\mathrm{E}(-)$ control $(0.55 \pm 0.15 \mathrm{~g} / \mathrm{mg}$ w.w., $\mathrm{n}=18$, Fig. 2A). The normalized concentration-response curve in $\mathrm{E}(-)$ control significantly shifted to the left compared with that in $\mathrm{E}(-)$ fresh [Fig. $2 \mathrm{~B} ; \mathrm{pD}_{2}$ for the $\mathrm{E}(-)$ fresh and $\mathrm{E}(-)$ control was 7.19 and 7.67 , respectively]. The concentration-response curve in E (-) FBS didn't change compared with that in $\mathrm{E}(-)$ control $\left[\mathrm{pD}_{2}\right.$ for the $\mathrm{E}(-)$ FBS; 8.16].

Endothelin (ET)-1-induced contraction in organ-cultured endothelium-intact rat mesenteric arteries: In E (+) fresh, 
A

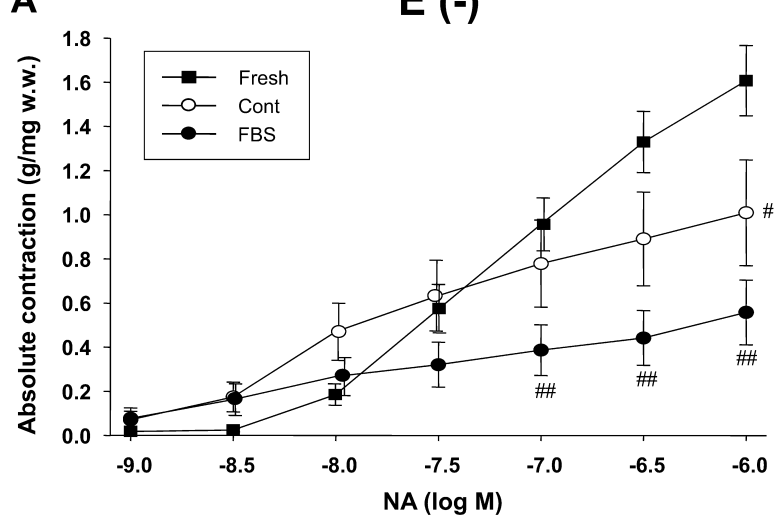

B

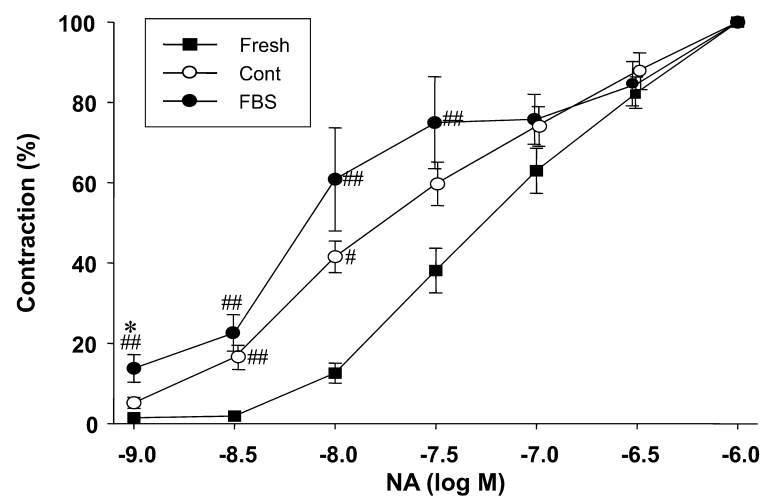

Fig. 2. Concentration-contraction relationship for NA in an endothelium-denuded [E (-)] rat mesenteric arteries; freshly isolated (fresh) or cultured in serum-free medium (cont) and with $10 \%$ FBS (FBS). Contraction was expressed as an absolute value (A: $\mathrm{g} / \mathrm{mg}$ w.w.) or normalized to the maximal contraction induced by $1 \mu \mathrm{M}$ NA (B). NA $(1 \mathrm{nM}-1 \mu \mathrm{M})$ was cumulatively applied. $100 \%$ represents the $1 \mu \mathrm{M}$ NA-induced maximal contraction. Results are expressed as means \pm SEM [fresh: $n=26$, control: $n=18$, FBS: $n=18$ (A); fresh: $n=20$, control: n=19, FBS: n=21 (B)]. \#, \#\#: Significantly different with $P<0.05$ and 0.01 vs. fresh. $*$ : Significantly different with $P<0.05$ vs. control.

ET-1 $(0.1-30 \mathrm{nM})$ induced contraction in a concentrationdependent manner with a maximal force of $2.46 \pm 0.31 \mathrm{~g} / \mathrm{mg}$ w.w. (n=11, Fig. 3A). In E (+) control, ET-1 (0.1-30 nM) caused contraction with a similar but slightly decreased maximal force compared with that in $\mathrm{E}(+)$ fresh $(1.78 \pm$ $0.27 \mathrm{~g} / \mathrm{mg}$ w.w., n=14, Fig. 3A). In E (+) FBS, the maximal contractile force induced by ET-1 $(30 \mathrm{nM})$ significantly increased than that in $\mathrm{E}(+)$ control $(2.83 \pm 0.33 \mathrm{~g} / \mathrm{mg}$ w.w., $\mathrm{n}=12$, Fig. $3 \mathrm{~A}, P<0.05)$. The normalized concentrationresponse curve in $\mathrm{E}(+)$ control shifted to the left compared with that in $\mathrm{E}(+)$ fresh [Fig. 3B; $\mathrm{pD}_{2}$ for the $\mathrm{E}(+)$ fresh and $\mathrm{E}(+)$ control was 8.07 and 8.26 , respectively]. The concentration-response curve in E (+) FBS didn't change compared with that in $\mathrm{E}(+)$ control $\left[\mathrm{pD}_{2}\right.$ for the $\left.\mathrm{E}(+) \mathrm{FBS} ; 8.17\right]$.

ET-1-induced contraction in organ-cultured endothelium-denuded rat mesenteric arteries: In E (-) fresh, ET-1
A

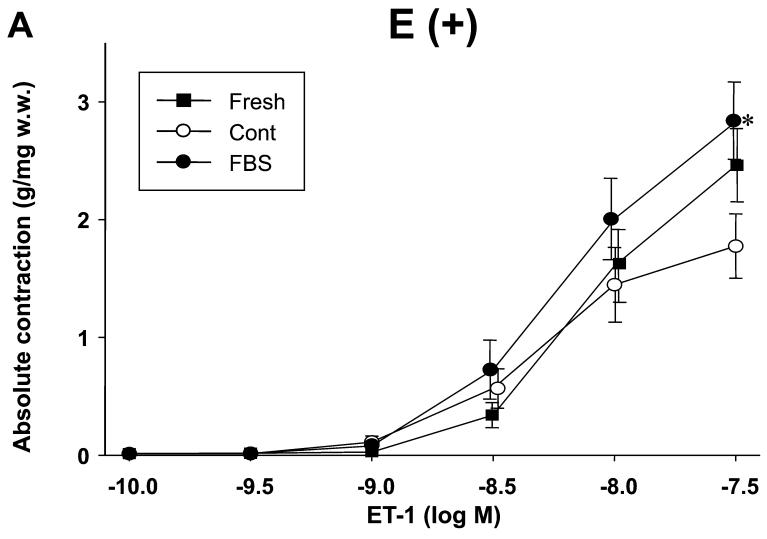

B

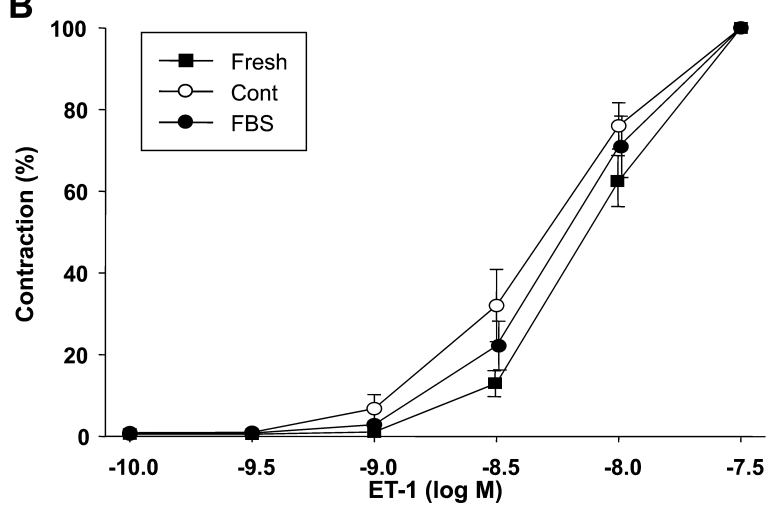

Fig. 3. Concentration-contraction relationship for endothelin-1 (ET-1) in an endothelium intact [E (+)] rat mesenteric arteries; freshly isolated (fresh) or cultured in serum-free medium (cont) and with $10 \%$ FBS (FBS). Contraction was expressed as an absolute value (A: $\mathrm{g} / \mathrm{mg}$ w.w.) or normalized to the maximal contraction induced by $30 \mathrm{nM}$ ET-1 (B). ET-1 $(0.1-30 \mathrm{nM})$ was cumulatively applied. $100 \%$ represents the $30 \mathrm{nM}$ ET-1induced maximal contraction. Results are expressed as means \pm SEM (fresh: $\mathrm{n}=11$, control: $\mathrm{n}=14$, FBS: $\mathrm{n}=12$ ). *: Significantly different with $P<0.05$ vs. control.

(0.1-30 nM) induced contraction in a concentration-dependent manner with a maximal force of $2.98 \pm 0.33 \mathrm{~g} / \mathrm{mg} \mathrm{w} . \mathrm{w}$. $(\mathrm{n}=18$, Fig. 4A). In E (-) control, ET-1 $(0.1-30 \mathrm{nM})$ caused contraction with a similar but slightly decreased maximal force compared with that in E (-) fresh $(2.23 \pm 0.47 \mathrm{~g} / \mathrm{mg}$ w.w., n=10, Fig. 4A). In E (-) FBS, ET-1 (0.1-30 nM) caused contraction with a slightly decreased maximal force compared with that in $\mathrm{E}(-)$ control $(1.71 \pm 0.44 \mathrm{~g} / \mathrm{mg}$ w.w., $\mathrm{n}=13$, Fig. 4A). The normalized concentration-response curve in $\mathrm{E}(-)$ control shifted to the left compared with that in $\mathrm{E}(-)$ fresh [Fig. 4B; $\mathrm{pD}_{2}$ for the $\mathrm{E}(-)$ fresh and $\mathrm{E}(-)$ control was 8.17 and 8.36 , respectively]. The concentrationresponse curve in E (-) FBS didn't change compared with that in $\mathrm{E}(-)$ control $\left[\mathrm{pD}_{2}\right.$ for the $\left.\mathrm{E}(-) \mathrm{FBS} ; 8.28\right]$.

5-hydroxytriptamine (5-HT)-induced contraction in organ-cultured endothelium-intact rat mesenteric arteries: In $\mathrm{E}(+)$ fresh, 5-HT (30 $\mathrm{nM}-30 \mu \mathrm{M})$ induced contraction in a concentration-dependent manner with a maximal force of 
A

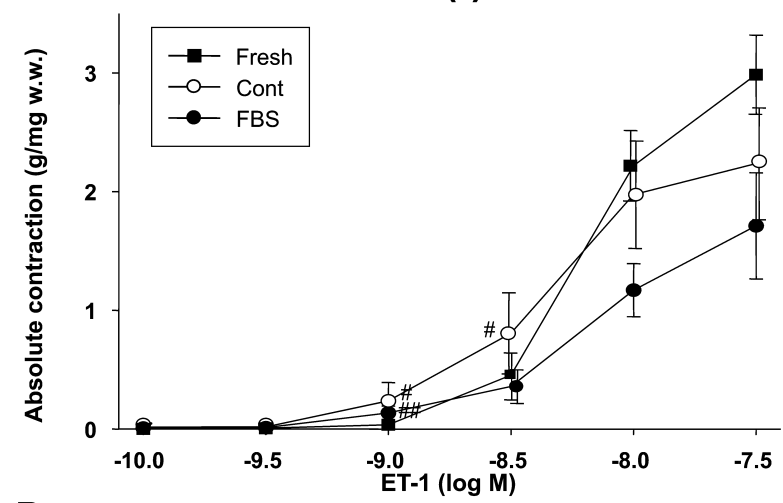

B

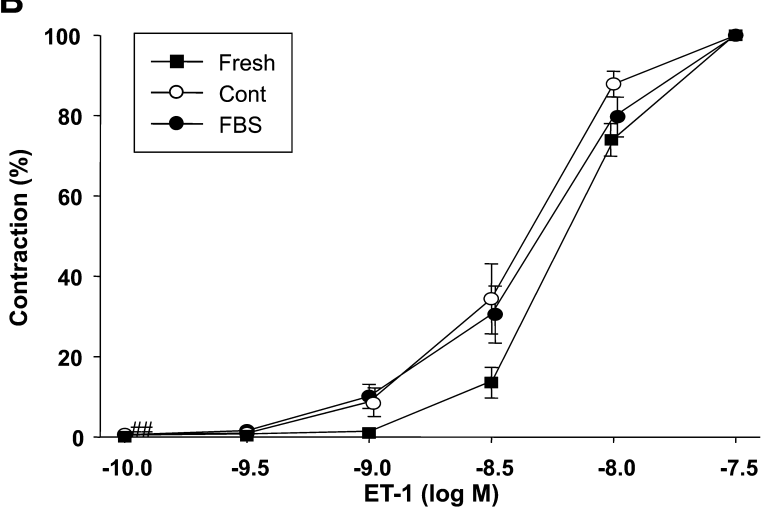

Fig. 4. Concentration-contraction relationship for ET-1 in an endothelium-denuded $[\mathrm{E}(-)]$ rat mesenteric arteries; freshly isolated (fresh) or cultured in serum-free medium (cont) and with $10 \%$ FBS (FBS). Contraction was expressed as an absolute value (A: $\mathrm{g} / \mathrm{mg}$ w.w.) or normalized to the maximal contraction induced by $30 \mathrm{nM}$ ET-1 (B). ET-1 $(0.1-30 \mathrm{nM})$ was cumulatively applied. $100 \%$ represents the $30 \mathrm{nM}$ ET-1-induced maximal contraction. Results are expressed as means \pm SEM [fresh $n=18$, control: $n=10$, FBS: $n=13$ (A); fresh: $n=18$, control $\mathrm{n}=10$, FBS: $\mathrm{n}=14$ (B)]. \#, \#\#: Significantly different with $P<0.05$ and 0.01 vs. fresh.

$1.51 \pm 0.25 \mathrm{~g} / \mathrm{mg} \mathrm{w} . w$. (at 5-HT $10 \mu \mathrm{M}, \mathrm{n}=15$, Fig. 5A). In E (+) control, 5-HT (30 nM-100 $\mu \mathrm{M})$ caused contraction with a similar but slightly decreased maximal force compared with that in $\mathrm{E}(+)$ fresh $(1.19 \pm 0.15 \mathrm{~g} / \mathrm{mg} \mathrm{w}$. w. at 5HT $100 \mu \mathrm{M}, \mathrm{n}=8$, Fig. 5A). In E (+) FBS, 5-HT (30 nM-100 $\mu \mathrm{M})$ caused contraction with a significantly increased maximal force compared with that in $\mathrm{E}(+)$ control $(2.21 \pm 0.44$ g/mg w.w. at 5-HT $100 \mu \mathrm{M}, \mathrm{n}=8$, Fig. 5A, $P<0.05)$. The normalized concentration-response curve in $\mathrm{E}(+)$ control significantly shifted to the right compared with that in $\mathrm{E}(+)$ fresh [Fig. 5B; $\mathrm{pD}_{2}$ for the $\mathrm{E}(+)$ fresh and $\mathrm{E}(+)$ control was 5.56 and 5.18, respectively]. The concentration-response curve in E (+) FBS significantly shifted to the right compared with that in $\mathrm{E}(+)$ control $\left[\mathrm{pD}_{2}\right.$ for the $\mathrm{E}(+) \mathrm{FBS}$; 4.66].

5-HT-induced contraction in organ-cultured endothelium-denuded rat mesenteric arteries: In E (-) fresh, 5-HT
A

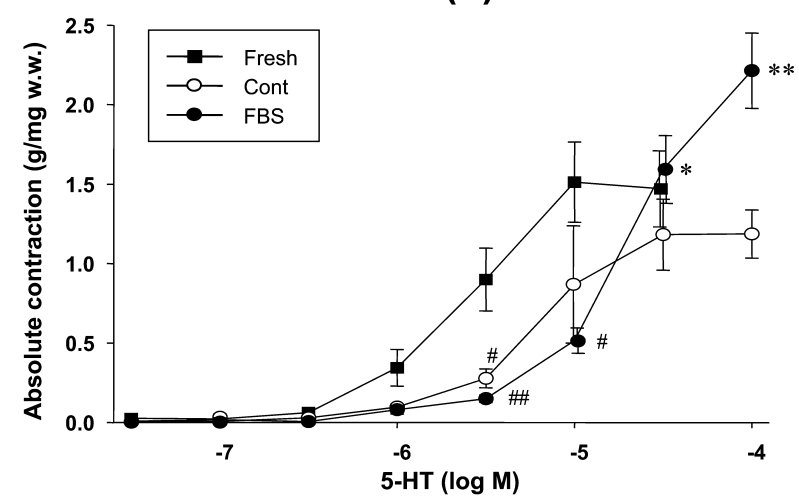

B

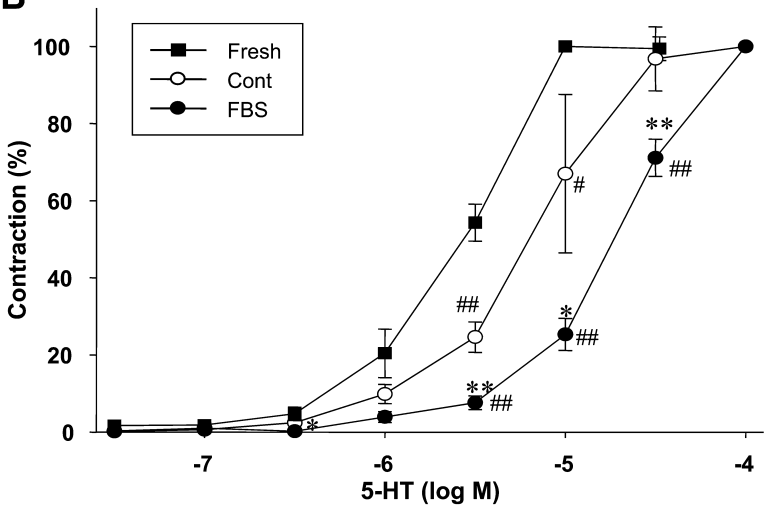

Fig. 5. Concentration-contraction relationship for 5-hydroxytriptamine (5-HT) in an endothelium intact [E (+)] rat mesenteric arteries; freshly isolated (fresh) or cultured in serum-free medium (cont) and with 10\% FBS (FBS). Contraction was expressed as an absolute value (A: $\mathrm{g} / \mathrm{mg}$ w.w.) or normalized to the maximal contraction induced by $10 \mu \mathrm{M}$ (fresh) or $100 \mu \mathrm{M}$ (cultured) 5-HT (B). 5-HT (30 nM-100 $\mu \mathrm{M}$ ) was cumulatively applied. $100 \%$ represents the $10-100 \mu \mathrm{M} 5$-HT-induced maximal contraction. Results are expressed as means \pm SEM (fresh: $\mathrm{n}=15$, control: $\mathrm{n}=8$, FBS: $\mathrm{n}=8$ ). \#, \#\#: Significantly different with $P<0.05$ and 0.01 vs. fresh. *, **: Significantly different with $P<0.05$ and 0.01 vs. control.

(30 nM-30 $\mu \mathrm{M}$ ) induced contraction in a concentrationdependent manner with a maximal force of $1.71 \pm 0.23 \mathrm{~g} / \mathrm{mg}$ w.w. (at 5-HT $10 \mu \mathrm{M}, \mathrm{n}=15$, Fig. 6A). In E (-) control, 5-HT (30 $\mathrm{nM}-100 \mu \mathrm{M})$ caused contraction with a similar but slightly decreased maximal force compared with that in $\mathrm{E}(-)$ fresh $(1.11 \pm 0.20 \mathrm{~g} / \mathrm{mg} \mathrm{w} . \mathrm{w}$. at 5-HT $100 \mu \mathrm{M}, \mathrm{n}=8$, Fig. $6 \mathrm{~A})$. In E (-) FBS, 5-HT (30 nM-100 $\mu \mathrm{M})$ caused contraction with a similar but slightly increased maximal force compared with that in $\mathrm{E}(-)$ control $(1.90 \pm 0.35 \mathrm{~g} / \mathrm{mg}$ w.w. at 5-HT $100 \mu \mathrm{M}, \mathrm{n}=11$, Fig. 6A). The normalized concentration-response curve in $\mathrm{E}(-)$ control significantly shifted to the right compared with that in $\mathrm{E}(-)$ fresh (Fig. $6 \mathrm{~B} ; \mathrm{pD}_{2}$ for the E (-) fresh and E (-) control was 6.10 and 5.09, respectively). The concentration-response curve in $\mathrm{E}(-)$ FBS significantly shifted to the right compared with that in $\mathrm{E}(-)$ control $\left[\mathrm{pD}_{2}\right.$ for the E (-) FBS; 4.57]. 

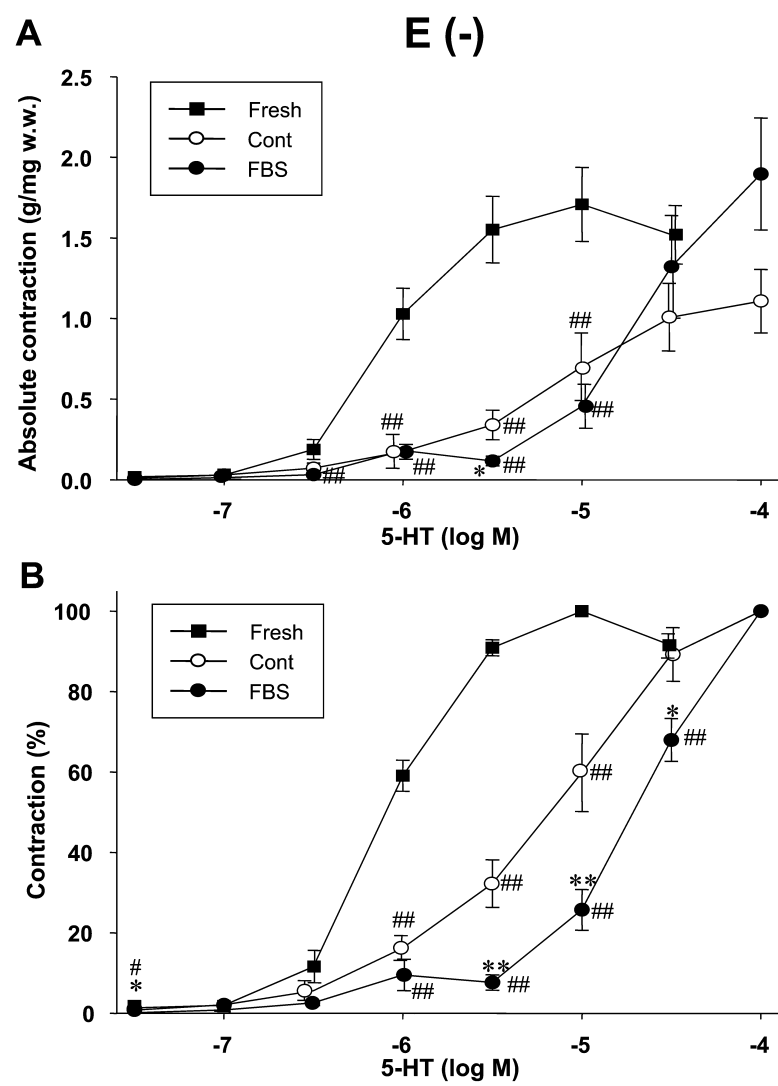

Fig. 6. Concentration-contraction relationship for 5-HT in an endothelium-denuded $[\mathrm{E}(-)]$ rat mesenteric arteries; freshly isolated (fresh) or cultured in serum-free medium (cont) and with $10 \%$ FBS (FBS). Contraction was expressed as an absolute value (A: $\mathrm{g} / \mathrm{mg}$ w.w.) or normalized to the maximal value induced by $10 \mu \mathrm{M}$ (fresh) or $100 \mu \mathrm{M}$ (cultured) 5-HT (B). 5-HT (30 nM-100 $\mu \mathrm{M}$ ) was cumulatively applied. $100 \%$ represents the 10-100 $\mu \mathrm{M} 5$-HT-induced maximal contraction. Results are expressed as means \pm SEM [fresh: $n=15$, control: $n=8$, FBS: $n=$ 11 (A); fresh: $n=15$, control: $n=8$, FBS: $n=12$ (B)]. \#, \#\#: Significantly different with $P<0.05$ and 0.01 vs. fresh. *, **: Significantly different with $P<0.05$ and 0.01 vs. control.

\section{DISCUSSION}

In the present study, we examined basic contractile characteristics in organ-cultured rat mesenteric arteries under serum-free condition compared with the freshly isolated ones, and further explored long-term effects of FBS on the contractile properties. It was concluded that 3-day organcultured rat mesenteric artery in the serum-free condition preserved an enough contraction to enable the analysis for long-term effects of drugs. Effects of FBS varied dependent on the types of agonists and/or the existence of endothelium.

Influences of serum-free organ culture on contractility of smooth muscle: In the present study, we demonstrated that contractile sensitivity to NA and ET-1 in control increased compared with that in fresh. It was previously shown that sensitivity to NA increased after a 7-day serum-free organ culture of rabbit mesenteric arteries [22]. Similarly, it was reported that sensitivity to an $\mathrm{ET}_{\mathrm{B}}$ agonist, sarafotoxin $6 \mathrm{c}$ increased after a 1-day serum-free organ culture of rat mesenteric arteries $[7,11,18,19]$. Several explanations are available to the increased sensitivity to agonists after serumfree organ culture; 1) up-regulation of receptor to each agonist, 2) activation of intercellular signaling pathways such as tyrosine kinase or protein kinase $\mathrm{C}(\mathrm{PKC}), 3$ ) increase in resting membrane potential by decreasing the expression and/or function of $\mathrm{K}^{+}$channels, or by increasing the expression and/or function of voltage-dependent $\mathrm{Ca}^{2+}$ channels and transient receptor potential channel (TRPC), 4) production of reactive-oxygen species (ROS). In rat mesenteric arteries cultured for 1 day in the serum-free medium, the upregulation of alpha $1 \mathrm{~A}$ adrenoreceptor [3] and $\mathrm{ET}_{\mathrm{B}}$ receptor $[7,11,18,19]$ was reported. With regard to the activation of intercellular signal pathways, a non-receptor tyrosine kinase, src-dependent increase of NA-induced contraction was reported in rat mesenteric arteries cultured in the serumfree condition for 2-3 days [16]. Additionally, it was reported in the same report that the expression of mRNA and protein of TRPC 6 increased after 2-3 days organ culture in the serum-free medium [16]. It was also reported in serum-free organ-cultured rat intrapulmonary arteries that the delayed rectifier voltage-gated $\mathrm{K}^{+}$current and non-inactivating $\mathrm{K}^{+}$current decreased after 4 days and that mRNA of several voltage-dependent $\mathrm{K}^{+}$channels including $\mathrm{Kv} 1.5$, Kv2.1 and a back-ground $\mathrm{K}^{+}$channel, TWIK-related acidsensitive $\mathrm{K}^{+}$channel (TASK)-1 decreased after 2 days [9]. In addition, it was reported in rat renal arteries cultured for 2 days in DMEM with $30 \mathrm{mM} \mathrm{K}^{+}$that the L-type $\mathrm{Ca}^{2+}$ current, expression of alpha $1 \mathrm{c}$ subunit of L-type $\mathrm{Ca}^{2+}$ channels, and $\mathrm{Ca}^{2+}$-dependent contraction increased [14]. We confirmed that the concentration-response curve to $\mathrm{K}^{+}(10$ $72 \mathrm{mM}$ ) in control shifted to the left compared with that in fresh ( $n=2-3$, data not shown), suggesting the increase in resting membrane potential. Finally, it was reported in rat mesenteric arteries cultured for $14 \mathrm{hr}$ in the low-serum (1\%) medium that relaxation induced by acetylcholine or sodium nitroprusside was impaired and that the impairment was reversed by the cell permeable super-oxide $\left(\mathrm{O}_{2}{ }^{-}\right)$scavenger, nicotinamide adenine dinucleotide phosphate (NADPH) oxidase inhibitor or xanthine oxidase inhibitor [5]. The results suggest that ROS may be produced from rat mesenteric arteries during organ culture. We observed that a ROS scavenger, tempol $(0.1 \mu \mathrm{M})$ did not reverse the left-ward shift in the concentration-response curve to NA and ET-1 in control ( $\mathrm{n}=3$, data not shown), suggesting that ROS might not be responsible for the increased sensitivity in our experiments. In the present study, we revealed that contractile sensitivity to 5-HT in control decreased compared with that in fresh. In contrast, it was previously reported in a 1day serum-free organ culture of rat mesenteric arteries that the sensitivity to 5-HT and the expression of 5- $\mathrm{HT}_{2 \mathrm{~A}}$-receptor increased compared with that in fresh $[2,8]$. It is speculated in our study that some of 5-HT receptor subtypes existing in fresh arteries are down-regulated during a 3-day 
organ culture.

In the present study, we found that the maximal force induced by NA, ET-1, or 5-HT in control was similar but slightly decreased compared with that in fresh. Similarly, it was previously shown that the NA-induced maximal force decreased in rabbit mesenteric arteries [22] and rat tail arteries [6] cultured for several days in the serum-free medium. The decrease in agonists-induced maximal contraction in serum-free organ-cultured artery might be due to the timedependent decrease in the amount of contractile protein presumably via protein catabolism, since morphological examination revealed the degenerative changes in the medial layer of control compared with fresh $(n=4$, data not shown).

Influences of organ culture with FBS on contractility of smooth muscle: In the present study we found that the maximal force induced by NA and ET-1 in E (+) FBS increased compared with that in $\mathrm{E}(+)$ control. Previously the decrease in endothelial nitric oxide (NO) synthase (eNOS) mRNA expression and the impairment of NO production were shown after 7-day organ culture of rabbit mesenteric arteries in the presence of FBS [21]. Therefore it might be possible that the decrease in endothelium-derived relaxing factors including NO could lead to the increase in the agonistsinduced maximal force. Further, 'uncoupling of eNOS' might be applicable to explain the increased maximal force in E (+) FBS. Uncoupled eNOS does produce not NO but $\mathrm{O}_{2}{ }^{-}$. Since $\mathrm{O}_{2}{ }^{-}$causes vasoconstriction $[17,20,23]$, the increase in maximal force in E (+) FBS may be caused by uncoupled eNOS-derived $\mathrm{O}_{2}^{-}$. It is well known that $\mathrm{NO}$ can regulate the activity of $\mathrm{Ca}^{2+}$ - or ATP-sensitive $\mathrm{K}^{+}$channels in vascular smooth muscle cells $[1,10]$. Thus, the decrease in NO production may affect ion-channels activities in vascular smooth muscle cells to increase the maximal contraction in $\mathrm{E}(+)$ FBS.

We found that the NA- and ET-1-induced maximal force in E (-) FBS decreased compared with that in E (-) control in contrast to the results of E (+) FBS. Morphological changes including proliferation, disorientation and death of smooth muscle cells in the medial layer after 7-day organ culture of rabbit mesenteric arteries in the presence of FBS are shown previously [22]. The structural changes were also reported after 4-day organ culture of rat tail arteries in the presence of FBS [6]. We also observed such morphological changes in the medial layer of FBS ( $n=4$, data not shown). The severity of the morphological changes was higher in $\mathrm{E}$ $(-)$ than E (+). Therefore, it is suggested that these morphological changes could cause the decrease in agonists-induced contraction. Furthermore, it is assumed that the disappearance of the protective effects of endotheliumderived NO may also enhance the morphological damage, since we observed that a NOS inhibitor, L-NAME decreased the NA-induced maximal contraction in $\mathrm{E}(+)$ FBS ( $\mathrm{n}=3$, data not shown).

Contrasting to NA and ET-1, we found that the sensitivity to 5-HT in FBS decreased compared with that in control. It is suggested that FBS further down-regulated the 5-HT receptor subtypes existing in fresh arteries. We also found that the 5-HT-induced maximal forces in E (+) or E (-) FBS increased compared with that in control. Up-regulation of different subtypes of 5-HT receptors may explain the increase of 5-HT-induced maximal force in FBS. Further studies are needed to determine which 5-HT receptor subtypes are expressed in organ-cultured arteries.

In summary, the present result demonstrated that 3-day organ-cultured rat mesenteric arteries in the serum-free condition preserved an enough contraction to enable the analysis for long-term effects of drugs. Long-term effects of FBS on contractility of isolated blood vessels vary dependent on the types of agonists and the existence of endothelium. The present study provides additional information on the basic contractile characteristics in organ-cultured rat mesenteric arteries for several days (3 days). By using this technique, it will become possible to investigate long-term effects of drugs on isolated blood vessels, which preserve contractile phenotype of smooth muscle cells, and to pharmacologically and pathologically clarify the mechanisms underlying the vascular contractile dysfunction seen in hypertension and/or diabetes.

ACKNOWLEDGMENTS. This study was supported in part by a Kitasato University Research Grant for Young Researchers, Grant for Scientific Research from the Kitasato University, School of Veterinary Medicine, and Grant for Sciencntific Research from the Japan Society for the Promotion of Science.

\section{REFERENCES}

1. Bolotina, V. M., Najibi, S., Palacino, J. J., Pagano, P. J. and Cohen, R. A. 1994. Nitric oxide directly activates calciumdependent potassium channels in vascular smooth muscle. Nature 368: 850-853.

2. Cao, Y. X., He, L. C., Xu, C. B., Luo, G. G. and Edvinsson L. 2005. Enhanced transcription of contractile 5-hydroxytryptamine $2 \mathrm{~A}$ receptors via extracellular signal-regulated kinase $1 / 2$ after organ culture of rat mesenteric artery. Basic. Clin. Pharmacol. Toxicol. 96: 282-288.

3. Cao, Y. X., Xu, C. B., Luo, G. G. and Edvinsson, L. 2006. Upregulation of alpha1A-adrenoceptors in rat mesenteric artery involves intracellular signal pathways. Basic. Clin. Pharmacol. Toxicol. 98: 61-67.

4. Gibbs, R. A., Weinstock, G. M., Metzker, M. L., Muzny, D. M., Sodergren, E. J., Scherer, S., Scott, G., Steffen, D., Worley, K. C., Burch, P. E., Okwuonu, G., Hines, S., Lewis, L., DeRamo, C., Delgado, O., Dugan-Rocha, S., Miner, G., Morgan, M., Hawes, A., Gill, R., Celera., Holt, R. A., Adams, M. D., Amanatides, P. G., Baden-Tillson, H., Barnstead, M., Chin, S., Evans, C. A., Ferriera, S., Fosler, C., Glodek, A., Gu, Z., Jennings, D., Kraft, C. L., Nguyen, T., Pfannkoch, C. M., Sitter, C., Sutton, G. G., Venter, J. C., Woodage, T., Smith, D., Lee, H. M., Gustafson, E., Cahill, P., Kana, A., Doucette-Stamm, L., Weinstock, K., Fechtel, K., Weiss, R. B., Dunn, D. M., Green, E. D., Blakesley, R. W., Bouffard, G. G., De, Jong. P. J., Osoegawa, K., Zhu, B., Marra, M., Schein, J., Bosdet, I., Fjell, C., Jones, S., Krzywinski, M., Mathewson, C., Siddiqui, A., Wye, N., McPherson, J., Zhao, S., Fraser, C. M., Shetty, J., 
Shatsman, S., Geer, K., Chen, Y., Abramzon, S., Nierman, W. C., Havlak, P. H., Chen, R., Durbin, K. J., Egan, A., Ren, Y., Song, X. Z., Li, B., Liu, Y., Qin, X., Cawley, S., Cooney, A. J., D'Souza, L. M., Martin, K., Wu, J. Q., Gonzalez-Garay, M. L., Jackson, A. R., Kalafus, K. J., McLeod, M. P., Milosavljevic, A., Virk, D., Volkov, A., Wheeler, D. A., Zhang, Z., Bailey, J. A., Eichler, E. E., Tuzun, E., Birney, E., Mongin, E., UretaVidal, A., Woodwark, C., Zdobnov, E., Bork, P., Suyama, M., Torrents, D., Alexandersson, M., Trask, B. J., Young, J. M., Huang, H., Wang, H., Xing, H., Daniels, S., Gietzen, D., Schmidt, J., Stevens, K., Vitt, U., Wingrove, J., Camara, F., Mar, Alba. M., Abril, J. F., Guigo, R., Smit, A., Dubchak, I., Rubin, E. M., Couronne, O., Poliakov, A., Hubner, N., Ganten, D., Goesele, C., Hummel, O., Kreitler, T., Lee, Y. A., Monti, J., Schulz, H., Zimdahl, H., Himmelbauer, H., Lehrach, H., Jacob, H. J., Bromberg, S., Gullings-Handley, J., Jensen-Seaman, M. I., Kwitek, A. E., Lazar, J., Pasko, D., Tonellato, P. J., Twigger, S., Ponting, C. P., Duarte, J. M., Rice, S., Goodstadt, L., Beatson, S. A., Emes, R. D., Winter, E. E., Webber, C., Brandt, P., Nyakatura, G., Adetobi, M., Chiaromonte, F., Elnitski, L., Eswara, P., Hardison, R. C., Hou, M., Kolbe, D., Makova, K., Miller, W., Nekrutenko, A., Riemer, C., Schwartz, S., Taylor, J., Yang, S., Zhang, Y., Lindpaintner, K., Andrews, T. D., Caccamo, M., Clamp, M., Clarke, L., Curwen, V., Durbin, R., Eyras, E., Searle, S. M., Cooper, G. M., Batzoglou, S., Brudno, M., Sidow, A., Stone, E. A., Payseur, B. A., Bourque, G., Lopez-Otin, C., Puente, X. S., Chakrabarti, K., Chatterji, S., Dewey, C., Pachter, L., Bray, N., Yap, V. B., Caspi, A., Tesler, G., Pevzner, P. A., Haussler, D., Roskin, K. M., Baertsch, R., Clawson, H., Furey, T. S., Hinrichs, A. S., Karolchik, D., Kent, W. J., Rosenbloom, K. R., Trumbower, H., Weirauch, M., Cooper, D. N., Stenson, P. D., Ma, B., Brent, M., Arumugam, M., Shteynberg, D., Copley, R. R., Taylor, M. S., Riethman, H., Mudunuri, U., Peterson, J., Guyer, M., Felsenfeld, A., Old, S., Mockrin, S. and Collins, F. 2004. Genome sequence of the Brown Norway rat yields insights into mammalian evolution. Nature 428: 493-521.

5. Jimenez-Altayo, F., Briones, A. M., Giraldo, J., Planas, A. M., Salaices, M. and Vila, E. 2006. Increased superoxide anion production by interleukin-1beta impairs nitric oxide-mediated relaxation in resistance arteries. J. Pharmacol. Exp. Ther. 316: $42-52$.

6. Lindqvist, A., Nordstrom, I., Malmqvist, U., Nordenfelt, P. and Hellstrand, P. 1999. Long-term effects of $\mathrm{Ca}^{2+}$ on structure and contractility of vascular smooth muscle. Am. J. Physiol. 277: C64-73.

7. Luo, G., Jamali, R., Cao, Y. X., Edvinsson, L. and Xu, C. B. 2006. Vascular endothelin $\mathrm{ET}_{\mathrm{B}}$ receptor-mediated contraction requires phosphorylation of ERK1/2 proteins. Eur. J. Pharmacol. 538: $124-131$

8. Luo, G., Xu, C. B., Cao, Y. X. and Edvinsson, L. 2004. Transcriptional up-regulation in expression of 5hydroxytryptamine $2 \mathrm{~A}$ and transcriptional down-regulation of angiotensin II type 1 receptors during organ culture of rat mesenteric artery. Basic. Clin. Pharmacol. Toxicol. 95: 280-
287.

9. Manoury, B., Etheridge, S. L., Reid, J. and Gurney, A. M. 2009. Organ culture mimics the effects of hypoxia on membrane potential, $\mathrm{K}^{+}$channels and vessel tone in pulmonary artery. Br. J. Pharmacol. 158: 848-861.

10. Miyoshi, H., Nakaya, Y. and Moritoki, H. 1994. Nonendothelial-derived nitric oxide activates the ATP-sensitive $\mathrm{K}^{+}$channel of vascular smooth muscle cells. FEBS Lett. 345: 47-49.

11. Moller, S., Uddman, E., Welsh, N., Edvinsson, L. and Adner, M. 2002. Analysis of the time course for organ culture-induced endothelin ET B receptor upregulation in rat mesenteric arteries. Eur. J. Pharmacol. 454: 209-215.

12. Mukohda, M., Yamawaki, H., Nomura, H., Okada, M. and Hara, Y. 2009. Methylglyoxal inhibits smooth muscle contraction in isolated blood vessels. J. Pharmacol. Sci. 109: 305-310.

13. Nomura, H., Yamawaki, H., Mukohda, M., Okada, M. and Hara, Y. 2008. Mechanisms underlying pioglitazone-mediated relaxation in isolated blood vessel. J. Pharmacol. Sci. 108: 258-265.

14. Pesic, A., Madden, J. A., Pesic, M. and Rusch, N. J. 2004. High blood pressure upregulates arterial L-type $\mathrm{Ca}^{2+}$ channels: is membrane depolarization the signal? Circ. Res. 94: e97-104.

15. Ross, R. 1993. The pathogenesis of atherosclerosis: a perspective for the 1990s. Nature 362: 801-809.

16. Tai, K., Vandenberg, G., Hamaide, M. C., Wibo, M. and Morel, N. 2009. Effect of organ culture on noradrenalineevoked contraction, calcium signalling and TRPC expression in rat mesenteric artery. J. Vasc. Res. 46: 353-364.

17. Touyz, R. M. 2005. Intracellular mechanisms involved in vascular remodelling of resistance arteries in hypertension: role of angiotensin II. Exp. Physiol. 90: 449-455.

18. Uddman, E., Adner, M. and Edvinsson, L. 2002. Protein kinase $\mathrm{C}$ inhibitors decrease endothelin ET(B) receptor mRNA expression and contraction during organ culture of rat mesenteric artery. Eur. J. Pharmacol. 452: 215-222.

19. Uddman, E., Henriksson, M., Eskesen, K. and Edvinsson, L. 2003. Role of mitogen-activated protein kinases in endothelin ETB receptor up-regulation after organ culture of rat mesenteric artery. Eur. J. Pharmacol. 482: 39-47.

20. Wang, Y. X. and Zheng, Y. M. ROS-dependent signaling mechanisms for hypoxic $\mathrm{Ca}(2+)$ responses in pulmonary artery myocytes. Antioxid. Redox. Signal. 12: 611-623.

21. Yamawaki, H., Sato, K., Hori, M., Ozaki, H. and Karaki, H. 1999. Impairment of endothelium-dependent relaxation in the arteries cultured with fetal bovine serum. Eur. J. Pharmacol. 366: $237-242$.

22. Yamawaki, H., Sato, K., Hori, M., Ozaki, H., Nakamura, S., Nakayama, H., Doi, K. and Karaki, H. 2000. Morphological and functional changes of rabbit mesenteric artery cultured with fetal bovine serum. Life Sci. 67: 807-820.

23. Yang, D., Feletou, M., Boulanger, C. M., Wu, H. F., Levens, N., Zhang, J. and Vanhoutte, P. M. 2002. Oxygen-derived free radicals mediate endothelium-dependent contractions to acetylcholine in aortas from spontaneously hypertensive rats. $B r . J$. Pharmacol. 136: 104-110. 